\title{
Pemberdayaan Perempuan Melalui Program Diet Kantong Plastik
}

\author{
Fika Ifazati \\ fikaifazati7@gmail.com \\ IAIN Purwokerto \\ Mita Nur Safitri \\ mitasafitri2012@gmail.com \\ IAIN Purwokerto
}

\begin{abstract}
The role of women in the public arena has been seen and held in high esteem by the community. This view is what makes women be able to take part in honing skills and swallowing college benches. Entrepreneurship in the industrial era as a form of maintaining good economic quality to live the wheel of life. The challenges faced in growing and developing an entrepreneurial spirit among women are very diverse ranging from capital, areas of expertise, limited production, long-term business, product market guarantees, quality of work, product quality, and minimal partnership. By using the research field the writer directly conducts interviews with business actors. This study aims to obtain a picture of how women are involved in the food stall business and create new innovations on the "plastic bag diet" and to explain the social situation in society about the role of women in entrepreneurship that is able to foster and give birth to new innovations. The results of the study indicate that the factor considered by producers is creating a business without eliminating the impact of the business, namely reducing the amount of plastic waste to protect the environment and giving lessons to students, especially in preserving nature.
\end{abstract}

Keywords: Women's Role, Entrepreneur, Food Stalls, Plastic Bag Diet

\begin{abstract}
Abstrak
Peranan wanita dalam kancah publike sudah dipandang dan dijunjung tinggi oleh masyarakat. Pandangan inilah yang menjadikan wanita mampu berkiprah mengasah skill dan menelan bangku perkuliahan. Berwirausaha di era industri sebagai bentuk mempertahankan kualitas ekonomi yang baik untuk menjalani roda kehidupan. Tantangan yang dibadapi dalam menumbubkan dan mengembangkan jiwa keevirausahaan pada kalangan wanita sangat beragam mulai dari modal, bidang keablian, keterbatasan
\end{abstract}




\begin{abstract}
produksi, usaha jagka panjang, jaminan pasar produk, kualitas kerja, kualitas produk, dan kemitraan yang minim. Dengan menggunakan research field penulis langsung melakukan wawancara kepada pelaku usaha. Kajian ini bertujuan untuk. memperoleh gambaran bagaimana wanita menggeluti usaha warung makan dan menciptakan inovasi-inovasi baru mengenai "diet kantong plastik." dan guna menjelaskan situasi sosial yang ada di masyarakat tentang peran wanita dalam berwirausaha yang mampu menumbubkan dan melabirkan inovasi baru. Hasil penenlitian menunjukan bahwa faktor yang dipertimbangkan oleh produsen adalah menciptakan usaba tanpa menghilangkan dampak dari usaha tersebut yaitu mengurangi jumlah sampah plastik untuk menjaga lingkungan dan memberi pelajaran kepada kalangan mashasiswa khususnya dalam melestarikan alam.
\end{abstract}

Kata Kunci: Peranan Wanita, Wirausaha, Warung Makan, Diet Kantong Plastik.

\title{
PENDAHULUAN
}

Keterpurukan atau kemiskinan yang dialami oleh masyarakat bukan hanya disebabkan oleh faktor sumber daya alam yang menipis, krisis moneter dan rata-rata pendapatan perkapita yang rendah. Akan tetapi penyebab yang paling dominan terjadiadalah kualitas sumberdaya manusia yang rendah, tidak memiliki kapasitas yang cukup untuk berhadapan dengan persaingan dan perubahan, demikian juga tidak cukup mampu untuk bertahan, menangkal dan mengantisipasi situasi atau kondisi yang terjadi. Dalam hal ini lembaga pendidikan, termasuk didalamnya lembaga pendidikan tinggi idealnya berfungsi dalam mewujudkan sumber daya manusia yang berkualitas; berwawasan luas, memiliki ketrampilan, jiwa sosial yang tingi, berkarakter dan memiliki kepribadian yang baik. Dengan adanya skillyang mumpuni seseorang atau individu dapat menjadi ahli dalam bidangnya apalagi dilengkapi jiwa kewirausahaan dan kepecayan diri yang baik. ${ }^{1}$

Pemberdayaan masyarakat merupakan sebuah pendekatan untuk merubah dan mencapai suatu kondisi masyarakat dari keterbelakangan menuju masyarakat yang lebih maju. ${ }^{2}$ Melalui

${ }^{1}$ Imam Santoso, Masalah Dan Tantangan Pengembangan Kewirausahaan Pada Kalangan Mahasiswa di Indonesia, Jurnal Inovasi dan Kewirausahaan. Vol. 3 No. 1, Universitas Jendral Soedirman, 2014.

2Sukirman, "Jiwa Kewirausahaan dan Nilai Kewirausahaan Meningkatkan Kemandirian Usaha Melalui Perilaku Kewirausahaan", Jurnal Ekonomi dan Bisnis, Vol. 20 No. 1, Fakultas Ekonomi. Universitas Muria Kudus, h. 118. 
Pemberdayaan masyarakat khususnya dibidang ekonomi akan dapat diwujudkanperubahan-perubahan positif dan kemajuan didalam masyarakat, dimulai dengan menanamkan sikap mandiri, tangguh, ulet, tekun dan berjiwa sosial tinggi. Pemberdayaan masyarakat dapat menciptakan kemandirian (kewirausahaan) khususnya kemandirian ekonomi. Melalui wirausaha mandiri seseorang atau individu dapat menaikan kelas sosial dalam sebuah masyarakat.

Semakin meningkatnyapertumbuhan enkonomi akibat dari revolusi industri 4.0 banyak pelaku bisnis dan wirausaha memanfaatkan perkembangan teknologi informasi, sehingga prinsipprinsip dasar desain industri 4.0 yang dikenal dengan revolusi digital karena terjadi proliferasi computer dan otomatisasi dan konektivitas disebuah bidang. ${ }^{3}$ Khusunya pengaruh dibidang perekonomian meningkat, dimana sektor-sektor membuka peluang untuk kewirausahaan dan UMKM meningkat begitu pesat. Dengan meningkatnya kemandirian ekonomi dapat mengurangi jumlah pengangguran dan memperluas kesempatan kerja karena maraknya wirausahawan sehingga teripta inovasi-inovasi baru dalam dunia industri. Tumbuhnya usaha mikro yang banyak dikelola wanita adalah sebagai bentuk mekanisme bertahan masyarakat miskin. ${ }^{4}$

Petumbuhan atau perubahan positif pada sektor ekonomi selalu menjadi isu hangat yang selalu diskursus di dunia ekonomi. Dan perubahan ekonomi selalu menjadi prioritas prioritas pembangunan yang dilakukan pemerintah, sekarang bahkan mungkin akan terus terjadi kedepan. Salah satu bentuk fondasi pembangunan ekonomi yang menjadi fokus perhatian adalah pembangunan kewirausahaan. Dalam hal ini kita belajar dari pengalaman di masa lalu yaitu krisis ekonomi, untuk menghadapi hal tersebut kita banyak belajar dari negara tetangga yaitu dengan belajar dengan tekun, menanamkan dan mengembangkan jiwa kewirausahaan serta mengasah skill.

${ }^{3}$ Hamdan, "Industri 4.0 Pengaruh Revolusi Industri Pada Kewirausahaan Demi Kemandirian Ekonomi”, Jurnal Nusamba, Vol. 3 No. 2, Universitas Serang Raya, 2018. h. 1.

${ }^{4}$ Thahya Whisnu Hendratni dan Ermalina, "Womenpreneur Peranan dan Kendalanya dalam Kegiatan Dunia Usaha", Jurnal Liquitidy, Vol. 2 No. 2, Universitas Pancasila, 2013. h. 3. 
Memliki jiwa berwirausaha tidak hanya dominasi kaum lelaki, tetapiperempuan juga terus tergerak dalam menciptakan usaha sekaligus mengembangkan skill yang mampu menumbuhkan inovasi baru, sehingga kaum wanita berkontribusi mengurangi beban ekonomi keluarga dan masyarakat. Meningkatnya angka buruh wanita di Indonesia, disatu sisi memunculkan berbagai persoalan sosial seperti persoalan buruh migran, pekerja pabrik dan makin tingginya eksploitasi untuk meraih sensasionalitas dan komersialisme, apalagi jika dikaitkan dengan kenyataan tingkat pendidikan tenaga kerja perempuan (wanita) yang sebagian besar masih sangat rendah. Kurangnya pendidikan dan skill yang dimilki belum mumpuni menyebabkan perempuan bekerja di sektor-sektor yang ber-resiko tinggi (risky) dengan upah yang minim.

Menumbuhkan semangat kewirausahaan khususnya di kalangan perempuan agaknya menjadi alternative solusi dari persoalan psikososial yang dialami oleh kaum perempuan di dunia kerja industri. Dan kenyataannya dunia kewirausahaan merupakan salah satu bidang yang sudah dipilih oleh banyak kaum perempuan untuk mengaktualisasikan potensi diri kaum perempuan di dunia ekonomi. Apalagi secara sejatinya memang perempuan memilki potensi ketekunan, kemauan, dan keinginan untuk bekerja keras sehingga perempuan mampu untuk merintis, mengelola dan mengembangkanusaha ekonomi, baik berskala kecil, menengah bahkan berskala besar.

Di era sekarang fenomena yang ada menunjukkan bahwaperempuan mampu menyeimbangkan antara wilayah kerja sektor domestik dan sektor public. Dalam budaya klasik, perempuan lebih ditempatkan di area kehidupan domestic. Sehingga dikenal istilah konco wingking, dimana perempuan diidentikkan dengan dapur, sumur, kasur. Kesan seperti itu semakin luntuk karena perempuan sudah mulai aktif di berbagai bidang baik sosial, ekonomi dan polotik, karena perempuan sudah menjadi bagian penting dalam sektor pembangunan. Hal ini juga tidak lepas dari jumlah perempuan di Indonesia yang lebih banyak dari kaum laki-laki menurut data lebih $50 \%$ dari 250 juta penduduk adalah perempuan.

Peranan perempuan dalam menciptakan usaha-usaha baru mulai tumbuh dan berkembang, baik di desa maupun kota, baik kaum perempuan muda maupun tua. Salah satu usaha yang digeluti oleh perempuan adalah membuka usaha warung makan, dimana perempuan benar-benar memiliki basic dalam mengolah berbagai jenis makanan. Warung makan khususnya di area kampus menjadi bisnis 
yang menjanjikan. Bisnis warung makan menjadi bagian dari upaya pemenuhan kebutuhan konsumen, utamanya dengan memberiukan pelayanan dan penyediaan kebutuhan konsumsi kosumennya. Dengan memberikan kepuasan pelayanan, maka bisnis kuliner bisa memberikan daya tarik dan kepuasan tersendri bagi pelanggannya. Pengukuran kepuasan pelanggan yaitu dari dimensi positif cara pelayanannya (keramahan, tanggapan, konsistensi rasa masakan). Menurut Moenir bentuk-bentuk pelayanan terdiri dari (1) pelayanan dengan lisan (2) pelayanan dengan tulisan (3) pelayanan dengan perbuatan. ${ }^{5}$

Namun demikian dalam konteks bisnis kuliner dan bahan makananan, terdapat beberapa persoalan yang muncul sebagai dampak dari pertumbuhan usaha serta prilaku konsumennya. Salah satu bentuk pelayanan yang menjadi kebutuhan konsumen dalam konteks bisnis bahan makanan dan kuliner adalah tuntutan dan kebutuhan terhadap bahan pembungkus dan kemasan yang diperlukan. Salah satu realitas dari relasi konsumen dan penyedia pelayanan adalah pemakaian bahan kemasan plastic sebagai kemasan wadah atau pembungkus makanan. Produksi sampah yang semakin hari semakin meningkat dirasakan sebagai masalah serius dalam menjaga kelestarian lingkungan hidup. Pemakaian bahan kemasan plastik yang sudah membudaya dirasakan dan disadari sebagai masalah yang harus dicari solusinya.

Dalam konteks ini di masyarakat muncul beberapa wacana, pemikiran bahkan gerakan dan tindakan, baik untuk mengurangi pemakaian bahan plastik maupun, mengurangi produksi sampah plastik maupun mengolah sampah plastik menjadi aneka produk kerajinan.

Warung 'Mamake' sebagai sebuah warung yang menyediakan pelayanan konsumsi makanan, adalah bagian dari warung atau penyedia jasa pengadaan bahan makanan yang ada. Kesadaran terhadap akibat negative dari penggunaan plastik secara massif yang mengancam kelestarian lingkungan mendorong dan memotivasi owner warung ini untuk mencari dan menerapkan langkah terobosan. Warung MAMAKE mengambil langkah yang tidak biasa dalam hal

5Julita. 2001. Menuju Kepuasan Pelanggan Melalui Penciptaan Kualitas Pelayanan. Jurnal Ilmiah 'Manejemen dan Bisnis. Vol. 1 No. 1. Program Studi Manejemen. Fakultas Ekonomi. Universitas Muhammadiyah Sumatra Utara, 2001. h. 43 . 
pengurangan sampah plastik. Diantara terobosan kreatif yang diterapkan oleh warung makan ini adalah pendekatan edukatif dengan menanamkan peduli lingkungan pada para pelanggannya dengan mengadakan diet kantung plastik. Penelitian ini merupakan upaya mendeskripsikan inovasi sosial yang dilakukan oleh pemilik warung ini dengan pendekatan edukatif yang dilakukan dalam mengurangi produksi sampah plastic.

\section{PEMBAHASAN}

\section{Peranan Wirausabawan Wanita}

Peranan merupakan hal dinamis dari sebuah kedudukan (status). Dengan hal ini, jika seseorang telah melakukan hak-hak dan kewajiban-kewajiban atas kedudukannya, maka orang tersebut telah melaksanakan suatu peran. Dalam hai ini, peran dan kedudukan mempunyai kerikatan satu sama lain atau tidak bisa dipisahkan, seperti halnya kedudukan, dari sini maka setiap manusia mempunyai bermacam-macam peran sesuai dengan pergaulan hidupnya. Dengan ini, peran juga banyak menentukan perbuatannya bagi masyarakat dan kesempatan-kesempatan yang akan diberikan dari masyarakat. Peran juga sangat mempengaruhi perilaku seseorang, juga dapat menumbuhkan pengertian kepada orang lain juga, sehingga peran menjadikan seseorang menyesuaikan perilakunya sendiri dan masyarakat sekitar.

Peran yang melekat dalam seseorang harus dibedakan dengan tempatnya dalam pergaulan, tempat atau posisi seseorang dalam masyarakat (social position) merupakan sebuah unsur yang statis dalam sebuah kelompok masyarakat. Sedangkan sebuah peran lebih menunjuk kepada fungsi, yang seseorang menduduki sebuah posisi dalam sebuah masyarakat sehingga seseorang tersebut menjalankan perannya tersebut.

Peran Wanita dalam hal ini merupakan suatu kemampuan wanita dalam mengembangkan usaha yang terfikir dalam pikirannya, Dalam konteks ini wanita juga banyak mempunyai peran yang penting dalam sebuah usaha dalam rangka meningkatkan pendapatan dalam sebuah rumah tangga. Pada perananannya juga wanita memiliki hal untuk mengatur manajemen waktu antara keluarga dan usaha 
sehingga hal tersebut menjadi terjadwal dengan baik antara keluarga dan usahanya pun dapat berjalan dengan lancar. ${ }^{6}$

Pada tingkatan masyarakat seorang wanita memiliki keinginan untuk membantu atau berpartisipasi dengan dunia kerja karena memang adanya peluang kerja yang menjanjikan, sehingga seorang wanita mempunyai peran yang sangat penting karena bukan untuk sambilan, dan dianggap tokoh yang penting dalam sebuah keluargauntuk mensejahterakan keluarganya.

Dalam konteks ini, seorang wanita juga mempunyai peran yang penting juga dalam pengelolaan dan pengembangan usaha, seorang wanita juga menumpahkan segara ketrampilan dan gagasannya serta keinginannya agar sebuah usaha yang dijalaninya berjalan sesuai dengan apa yang diharapkannya, sehingga peran wanita dalam sebuah usaha merupakan hal yang berangkat dari keinginan yang diwujudkan dalam sebuah usaha, dan terciptalah pengusaha wanita. ${ }^{8}$

Kewirausahaan merupakan sebuah proses pengembangan yang dalam hal ini membawa visi dalam sebuah kehidupan. Visi yang dimaksud adalah berupa ide atau peluang yang dianggap lebih baik dalam menjalankan sebuah usaha agar mencapai kesuksesan. Dapat ditegaskan bahwa untuk menciptakan sebuah usaha diperlukan adanya kemampuan dari individu tersebut untuk menghadapi tantangan dalam dunia usaha. ${ }^{9}$

Banyak usaha yang telah berdiri dari mulai usaha kecil sampai besar, sehingga mempunyai pola pengelolaan yang berbeda-beda, seperti halnya usaha warung makan ini memang masih seperti layaknya warung makan pada umumnya. Tapi dalam hal ini usaha warung makan ini mempunyai halyang menarik yaitu jum'at berkah yang dimana para pelanggan mendapat es teh secara gratis pada

'Siti Munfaqiroh, 2016, "Faktor yang mempengaruhi Wirausaha Wanita Miskin Untuk Mencapai Keberhasilan Usaha”, Jurnal JIBEKA, Vol 10 No 1, STIE Malangkucecwara Malang, 2016, h. 59

${ }^{7}$ Annisa Mardatilah, "Peran Wanita dalam Pengembangan Usaha Kecil Rumah Tangga untuk Meningkatkan Pendapatan Keluarga", JIS, UIR, Vol 5 No 2, 2016, h. 209

${ }^{8}$ Rizki Kusumadewi Saputri \& Fathul Himam, "Mindset Wanita Pengusaha Sukses", Jurnal Psikologi, Vol 42 No 2, Universitas Gadjah Mada, 2015, h. 160

${ }^{9}$ Ernani Hadiyat, "Kreativitas dan Inovasi Berpengaruh Terhadap Kewirausahaan Usaha Kecil", Jurnal Manajemen dan Kewirausahaan, Vol 13 No 1, Universitas Gajayana Malang, 2011, h. 10 
setiaphari jum'at, tujuan dari wirausahawan sendiri memang hanya dengan untuk mengucapkan terima kasih pada para pelanggan.

Dalam sebuah usaha juga perlu melihat peluang-peluang untuk menciptakan nilai baru yang dapat menyebabkan nilai tambah dipasaran yang mempunyai keunggulan, dan mempunyai kemampuan mengambil resiko atas apa yang dijalani atau lebih tepatnya lebih berani mengambil langkah baru yang sesuai dengan situasi sekitar. ${ }^{10}$

Usaha yang terbentuk disini merupakan usaha yang memang melihat peluang yang ada, khususnya banyak mahasiswa yang bermukim didekat kampus dan adanyabeberapa pondok yang berdiri dikawasan kampus, sehingga terbentuklah sebuah usaha yaitu warung makan yang menyediakan nasi dan lauk pauk yang memang kebutuhan wajib bagi setiap manusia.

Sehingga penulis sendiri menegaskan bahwa peranan wirausahawan wanita adalah wanita yang memiliki peranan penting dalam membangun sebuah usahanya, sehingga dapat membentuk jiwa mandiri dan tidak bergantung pada orang lain sebagai pemenuh kebutuhan perekonomian keluarga.

\section{Inovasi Diet Kantong Plastik}

Inovasi merupakan sebuah gambaran baru atau kreativitas yang dapat diterapkan dan mampu memberikan nilai yang menambah atas sumber daya yang sudah ada. Dalam sebuah inovasi seseorang memerlukan gagasan atau sebuah ide yang kreatif untuk melihat kesempatan yang ada dalam masyarakat sekitar. Secara umum, inovasi juga tidak melulu tentang ide yangbaik tapi inovasi merupakan suatu ide yang dimatangkan konsepnya untuk kemudian diimplementasikan. Dengan demikian inovasi merupakan sebuah kombinasi antara kreativitas, ide, visi serta dedikasi untuk mengimplementasikan sebuah ide atau gagasan yang telah dirumuskan.

Dalam inovasi juga adanya perasaan tidak puas atas kondisi masyarakat yang ada serta adanya peluang dalam rangka memperbaiki keadaan yang telah ada, jadi sebuah inovasi bisa dijadikan alat untuk

${ }^{10}$ Tejo Nurseto, "Strategi Menumbuhkan Wirausaha Kecil Menengah yang Tangguh", Jurnal Ekonomi dan Pendidikan, Vol 1 No 1, Universitas Negeri Yogyakarta, 2004, h. 98 
memperbaiki kondisi untuk lebih baik lagi. Dengan ini sumber yang dilakukan untukinovasi sendiri merupakan pelaksanaan dan sebuah hasil dari seorang wirausahawan untuk memanfaatkan perubahan agar lebih baik lagi. ${ }^{11}$

Inovasi juga memiliki sebuah proses yang merupakan doronngan lahirnya sebuah inovasi tersebut, dari sini sebuah inovasi muncul karena adanya arah untuk melihat, mendengar dan bertanya serta mendengarkan orang lain untuk memberikan idenya dalam mencari inovasi yang memang akan memperhatikan hal yang ada di sekitar masyarakat sekitar. Sehingga dari sini sang innovator akan memikirkan hal yang memang tepat untuk diterapkan, biasanya hal tersebut yang dilihat sederhana tapi sebenarnya memiliki dampak yang begitu besar bagi sekitar.

Dari sini kata "Diet" terlihat umum terdengar, tapi jika ini adalah "Diet Kantong Plastik" mungkin terdengar agak unik, memang istilah "Diet Kantong Plastik disini menggambarkan sebagai gaya hidup untuk mengurangi banyaknya limbah plastik ${ }^{12}$

Kantong plastik adalah salah satu barang yang lekat ada pada kehidupan keseharian kita, yang mana kantong plastik merupakan komponen utama yang diberikan penjual kepada pembeli untuk membungkus barang belanjaannya, memang kantong plastik menjadi pilihan utama karena memang lebih praktis digunakan dalam kehidupan sehari-hari, memudahkan untuk membawa barang-barang belanjaan, sehingga dari sini menggambarkan bahwa pembeli menjadi konsumen atau pengguna utama dari kantong plastik itu sendiri, baik secara aktif maupun pasif

Barang-barang yang berbahan plastik merupakan bahan yang terbuat dari polimer sintesis yang sulit untuk terurai dialam, yang butuh bratus-ratus tahun untuk dapat terurai, dalam hal ini,

${ }^{11}$ Irma Paramita Sofia, "Konstruksi Model Kewirausahaan Sosial (Social Entrepreneurship) sebagai gagasan Inovasi Sosial Bagi Pembangunan Perekonomian", Jurnal Universitas Pembangunan, Vol 2 No 2, Universitas Pembangunan Jaya, 2015, h. 6-7

${ }^{12}$ Oki Achmad Ismail, "Promosi Kampanye Diet Kantong Plastik Oleh Greeneration Indonesia", Jurnal Ilmu Politik dan Komunikasi, Vol 7 No 1, Universitas Komputer Indonesia, 2017, h. 98 
peningkatan penggunaan kantong plastik yang sangat meningkat, dan sangat memungkinkan rusaknya keseimbangan alam. ${ }^{13}$

Kantong plastik sendiri sebenarnya menimbulkan dampak negatif terhadap lingkungan, seperti halnya sampah plastik yang terbuang di aliran sungai atau laut yang dapat mencemari kehidupan hewan-hewan yang ada di air, didarat pun tak luput dari dampak negatif dari sampah lastik itu sendiri, tanah yang didalamnya mengandung plastik dapat mengurangi tingkat kesuburan tanah itu sendiri, sampah yang banyak menumpuk pun dapat menyebabkan banyak dampak negative seperti pembakaran sampah plastikpun dapat menimbulkan gangguan pernafasan dan lain-lain bagi manusia. Sehingga dari sini sebenarnya limbah plastik sangat berbahaya terhadap lingkungan dan manusia itu sendiri, dan oleh karena itu kita pun harus mampu melestarikan lingkungan yang tentunya ramah lingkungan.

Dari sini "Inovasi Diet Kantong Plastik" merupakan suatu alternatif untuk mengurangi limbah plastik dengan cara menghemat penggunaan kantong plastik sekali pakai dan digantikan dengan kantong yang terbuat dari kain yang dapat digunakan berkali-kali (totebag), dalam hal ini inovasi diet kantong plastic mampu mengurangi limbah plastik yang mencemari lingkungan.

Industri kreatif di Indonesia sangat beragam dan memilki nilai jual yang tinggi baik di desa maupun kota. Semua orang memiliki bakat dan ketrampilannya masing-masing, apalagi wanita di era yang canggih seperti ini semakin baik jika wanita memiliki usaha nya sendiri tanpa harus bergantung pada pasangannya secara penuh. Dengan memiliki greget pada kewirausahaan (entrepreneurship) dalam dirinya, maka akan menghasilkan produk yang inovatif, kreatif dan bernilai jual.

Menurut Cerald Merwell dan Talcot Parson Pembagian peran kerja secara seksual merupakan akibat wajar dari kodrat wanita itu sendiri. Perbedaan sksual selalu terjadi, meskipun betuknya tidak selalu sama. Pada setiap kebudayaan wanita dan pria di beri peran dan pola tingkah laku yang berbeda dan berfungsi saling melengkapi kekurangan masing-masing. ${ }^{14}$

${ }^{13}$ Reni Silvia Nasution, "Berbagai cara penanggulangan Limbah Plastik", Journal of Islamic Science and Technology, Vol 1 No 1, UIN Ar-Raniry, 2015, h. 99

${ }^{14}$ Ariyani Indrayati, "Peranan Wanita Dalam Pemberdayaan Ekonomi Lokal” (Studi Kasus Tentang Pola Ruang Belanja Wanita di Daerah Pinggiran Kota 
Perkembnagan zaman yang semakin canggih dan kemajuan pembangunan, menjadikan pergeseran peran wanita kususnya dari peran-peran rumah tangga (domestic role) menjadi peran yang lebih berorientasi pada masyarakat luas atau publik (public role) yaitu bekerja tidak didalam rumah atau pengurus dapur. Sebagai konsekuensi dari itu semua wanita memilki peranan ganda dengan segala permasalahannya, yaitu bekerja di ranah domestic wanita juga berperan dalam ranah publik. Namun dengan masuknya pria ke ranah domestik masih menjadi gejala yang mustahil dalam sebuah masyarakat Indonesia, nemun di zaman yang baru sudah mulai menunjukan perubahan yang makin nyata.

Kegiatan wanita terbagi atas dua ranah yaitu kegiatan dalam rumah tangga dan di luar rumah tangga baik ekonomi maupun non ekonomis. Kegiatan non ekonomis dalam rumah tangga yaitu kegiatan sehari-hari yang bukan berkaitan dengan mencari nafkah atau berkaitn erat dengan peran wanita sebagai seorang isteri. Sedangkan kegiatan yang bersifat non ekonomis di luar rumah tangga yaitu kegiatan sosial kemasyarakatan dan kegiatan yang bersifat keagamaan. Dan yang brsifat ekonomis yaitu kegiatan yang dapat mendatangkan pendapatan dan dikerjalan di luar rumah. ${ }^{15}$

Peranan wanita dalam rumah tangga menjadi dominan dari pada pria, khususnya dalam masalah pengeluaran seperti kebutuhan pokok, rekreasi, rekening, pendidikan dan lain-lain. Setiap wanita juga memiliki pola belanja yang berbeda-beda dalam memenuhi kebutuhan keluarganya. Penciptaan wanita dalam berwirausaha menjadikan wanita makin terdidik dan memiliki jiwa tanggung jawab yang besar akan kebutuhan. Memilki usaha sendiri menjadikan wanita makin mandiri apalagi dalam mengembangkan produk-produk yang akan dikeluarkan.

Produk adalah segala sesuatu yang bisa ditawarkan ke pasar supaya mendapatkan perhatian dan dibeli, digunakan, atau dikonsumsi yang mampu memberikan kepuaskan akan keinginan atau kebutuhan. Jadi dalam usaha warung makan produk yang disajikan adalah makanan sebagai sajian utama kepada konsumen.

Semarang), Jurnal Geografi. Vol. 7. No. 2, Fakultas Ilmu Sosial, Universitas Negeri Semarang, 2010, h. 90.

${ }^{15}$ Ariyani Indrayati, ibid. 
Dengan meningkatnya jumlah warung makan di daerah Banyumas khususnya daerah kampus IAIN Purwokerto, para pelaku usaha tak dapat mengandalkan satu produk atau jasa utamanya saja, para pelaku bisnis harus mempunyai trobosan-trobosan baru agar usaha yang dijalankannya bisa bertahan dalam persaingan yang semakin ketat. Dengan adanya konsep kreatif ditujukan agar pelanggan tidak merasa bosan dengan pelayanan dengan produkproduk yang tersedia, juga pelaku bisnis mempunyai kesempatan untuk terus dan bertahan lebih lama dengan adanya inovasi tersebut.

Dibutuhkan strategi untuk meningkatkan daya tarik konsumen dalam menghadapi persaingan bisnis yang makin kompetitif. ${ }^{16}$ Sehingga dibutuhkan penyajian produk alternatif yang menarik sebagai nilai tambah dalam produk utamanya. Konsumen sekarang lebih pandai dalam memilih produk terutama dalam memilih jenis makanan, tempatnya dan juga harga yang ditawarkan sebagai pertimbangan utama apalagi dikalangan mahasiswa.

Perkembangan bisnis yang makin pesat ini selalu mengarah pada persaingan yang ketat terutama bagi usaha sejenis. Tuntutan terhadap para pelaku bisnis adalah memiliki inovasi dan keunikan sebagai daya pikat konsumen dalam rangka merebut hati dan mempertahankan pangsa pasar yang ada. Menurut Tjahyadi istilah loyalitas pelanggan menunjukan pada kesetian pelanggan pada objek tertentu seperti merek, produk, jasa atau toko. Pada umumnya merek seringkali dijadikan sebagai objek loyalitas pelanggan. ${ }^{17}$ Di dalam warung makan yang tersaji di area kampus sudah menjadi hal dan pesaingan yang ketat antar pembisnis satu dengan yang lainnya kemudian yang menjadi loyalitas dalam penyajian produk makanan tersebut adalah menjaga cita rasa makanana, pelayanan dan kesetrategisan tempat juga dekorsi tempat, yang mana tidak menjadi kebosanan tersendiri bagi pelanggan yang makan ditempat.

Meningkatnya jumlah penduduk yang dikiuti dengan bertambahnya volume sampah yang ditimbulkan oleh aktivitas manusia itu sendiri, menjadi bagian dari masalah terutama yang berkaitan dengan upaya pelestarian lingkungan hidup. Sampah yang

${ }^{16}$ Andria Wijoyo, "Pengaruh Variable Marketing Mix terhadap Customer Loyalty Honda Ramayana Basuki Rachmad dengan Customer Satisfaction sebagai Variable Intervening", Jurnal Menejemen Pemasaran Petra,Vol. 2 No. 1, Program Menejemen Pemasaran, Universitas Kristen Petra, 2014, h. 1.

${ }^{17}$ Andria Wijoyo, "Pengaruh Variabel Marketing....., h. 1. 
dihasilkan adalah sampah organik (60-70\%) dan sampah non-organik (30-40\%) kemudian komposisi sampah non-organik yaitu $14 \%$ adalah plastik.Kemampuan plastik yang terbuat dari bahan organik yang dapat dibentuk apabila terpapar panas dan tekanan. Plastik dapat berbentuk batangan, lembaran, blok dan bila dalam bentuk produk atau kemasasan dapat berupa botol, pembungkus makanan dan lain-lain. Komposisi dan material plastik adalah polymer dan zat additive lainnya. Polymer tersusun dari monomer-monomer yang terikat oleh rantai ikatan kimia. ${ }^{18}$ Kebutuhan plastik domestik dalam sektor industri makanan dan minuman merupakan kebutuhan domestik yang tinggi, sehingga impor plastik terus menumpuk. ${ }^{19}$ Yang paling banyak jumlahnya adalah kantong plastik kantong kresek pembungkus belanjaan dan yang tak kita disadari dengan sampah rumah tangga yaitu sampah bekas shampo,sabun dan bungkus bumbu masakan,

Meskipun sampah plastik banyak mengakibatkan dampak negatif namun disisi lain palstik memilki dampak positif yaitu sangat mudah jika digunakan, mudah dicari, tahan lama, memilki materialmaterial yang kuat dan tidak gampang rusak serta tidak menyerap air. Dampak negatif yang ditimbulkan oleh sampah plastik yaitu mengurangi kesuburan tanah, jika di buang sembarangan bisa menyumbat saluran drainase, sungai sehingga dapat menimbulkan banjir. Dan apabila sampah plastik itu di bakar maka dapat mencemari udara yang apabila dihirup oleh manusia dapat menimbulkan sesak nafas karena zat-zat yang ditimbulkan sangat berbahaya.

Warung makan yang didirikan sejak 10 Maret 2017 ini oleh pasangan suami istri Siti rahmawati dan Giat Suryanto berawal dari adanya lahan kosong di deket area kos mahasiswa. Dari sinilah ibu dari tiga anak ini mendirikan warung makan kecil-kecilan, yang sebelumnya ia bekerja sebagai tukang kredit dimana ia hanya mendapat uang tiap bulannyaa sedangkan kebutuhan untuk hidupnya harus dipenuhi setiap hari. Dengan membuka usaha warung makan

${ }^{18}$ Pramiati Purwaningrum, "Upaya Mengurangi Timbulnya Sampah Plastik di Lingkungan”, JTL. Vol. 8 No. 2, Jurusan Teknik Lingkungan, Universitas Trisakti, 2016, h. 141.

${ }^{19}$ Wanda, "Upaya Menanggulangi Limbah Sampah Plastik dari Belanda", JOM FISIP, Vol. 6 No. 1, Jurusan Ilmu Hubungan Internasional, Universitas Riau, 2019, h. 2. 
ini ia dapat memenuhi kebutuhan sehari-hari tanpa menunggu jatah bulanan.

Konsumen (Consumer) berbeda dengan pelanggan (Customer), seseorang dikatakan pelanggan apabila orang tersebut sudah membiasakan membeli produk dan dilakukan secara berulang-ulang dalam waktu tertentu baik barang atau jasa yang ditawarkan oleh pelaku usaha tersebut. Sedangkan konsumen atau pembeli adalah seseorang dengan jangka waktu tertentu membeli barang atau produk tanpa melakukan pembelian ulang. ${ }^{20}$ Selanjutnya Giffin berpendapat bahwa seorang pelanggan dikatakan loyal atau setia bila mana terdapat suatu kondisi yang mewajibkan pelanggan membeli paling sedikit dua kali dalam selang waktu tertentu atau seoraang pelanggan tersebut melakukan pembelian secara teratur.

Warung makan yangdidirikan karena melihat tanah kosong disekitar pemikiman warga yang mana banayak diantara warga yang memilki kos dan berada dekat dengan salah satu pondok pesantren, menjadikan ibu beranak tiga ini memutar otak bisnisnya dengan mendirikan warung makan. Awal berdirinya usaha warung makan ini hanya dikerjakan oleh keluarganya, namun lama-kelamaan konsumen terus meningkat sehingga membutuhkan tenaga yang lebih untuk melayaninya. Tenaga yang dipekerjakan oleh ibu ini salah satunya yaitu janda dimana janda tersebut membutuhkan pekerjaan untuk memenuhi kebutuhan keluarganya. Dengan jiwa bisnis yang tinggi dan sebagai rasa terimaksih dan ucapan syukur kepada sang pencipta, ibu Rahmawati mengadakan "jumat berkah" dimana ia membagikan es teh gratis kepada pelanggannya.

Inovasi yang dicetuskan oleh Ibu Siti Rahmawati ini membawa arah gesekan tersendiri khusunya di kalangan pembisnis warug makan, yaitu mengurangi jumlah sampah plastik yang biasanya sehari dapat mengeluarkan 3-4 Kg palstik kantong per hari sekarang hanya 1-2 Kg kantong plastik per hari. Menurutnya sampah plastik yang dikeluarka setiap hari membawa dampak ngatif bagi lingkungan yaitu tidak bisanya plastik di urai oleh tanah, pembakaran plastik menjadikan pemanasan global, pemborosan pembelanjaan kantong plastik. Berangkat dari permasalahan inilah ibu dengan 3 anak ini

${ }^{20}$ Trisno Musanto, "Faktor-Faktor Kepuasan Pelanggan dan Loyalitas Pelanggan: Studi Kasus pada CV.Sarana Media Advertising Surabaya",Jurnal Menejemen \& Kewirausahaan, Vol 6 No. 2, Jurusan Ekonomi Manejemen, Universitas Katolik Widya Mandala Surabaya, 2004. 
membuat inovasi-inovasi baru yaitu dengan mengadaka diet sampah plastik. Yaitu dengan membeli totebag ukuran kecil $(30 \times 15 \mathrm{~cm})$ dengan harga Rp. 3.500,00 dan kartu pelanggan dimana didalamnya ada ketentuan: (1) setiap pembelian minimal Rp. 5.000,00 dapat satu poin dan kelipatannya (2) dengan 30 poin anda berhak mendapatkan 1 cup es kopi atau susu.

Usaha warung makan yang sudah berdiri 3 tahun makin melebarkan sayapnya. Pelaku bisnis wanita ini tidak pernah membuat brosur apapun terkait usaha warung makannya untuk lebih dikenal oleh konsumen-konsumen lain, namun warung makan "MAMAKE" selalu ramai oleh mahasiswa dan mahasiswi. Dengan pelayananpelayanan yang baik, ramah, dan tempat yang bersih serta harganya yang murah menjadikan warung makan ini tidak pernah sepi dari pelanggannya. Dengan makin ramainya pelanggan juga menambah karyawan baru dalam ikut andil memberikan pelayanan di warung makan. Karyawan-karyawan tersebut di ambil dari keluarga, sekitar rumah makan, dan juga janda yang tidak berpenghasilan, lewat pekerjaan inilah mereka para karyawan yang mayoritas ibu rumah tangga dapat memnuhi kebutuhan sehari-harinya.

\section{KESIMPULAN}

Berdasarkan penelitian yang telah dilakukan mengenai peran wanita usaha warung makan dalam inovasi diet sampah plastik ini, Pelaku usaha wanita,yang memiliki keunggulan-keunggulan yang memang secara alamiah ada dalam diri manusia. Peran wanita dalam hal ini merupakan tolak ukur bahwa wanita juga mempunyai peran yang penting disini, khususnya dalam sebuah usaha, setelah wanita melakukan perannya dalam sebuah keluarga.

Peran wanita yang tidak hanya dalam ranah domestik, tapi peran perempuan dalam melahirkan gagasannnya dalam ranah publik yaitu sebuah usaha yang diciptakannya, selain usaha sendiri peran wanita dalam melahirkan inovasi dari hal sederhana yang kadang masyarakat sendiri tidak memikirkannya, wanita memiliki kemampuan atau ide yang merupakan bentuk pemikirannya untuk dapat mematangkan gagasan, yang mereka sendiri juga tetap bertanya dan mendengarkan orang lain agar gagasannya juga sesuai dengan realitas yang ada. Dalam inovasi ini yang merupakan hal yang sangat menarik dari penamaan inovasi ini dalam warung ini, yaitu diet 
sampah plastik dan yang lebih baik lagi inovasi ini memiliki dampak yang baik bagi lingkungan sekitar.

Berbicara diet kantong plastik dalam hal ini, menjadikan manusia untuk menjalani gaya hidup yang ramah lingkungan yaitu meminimalisir penggunaan plastik sekali pakai ,dan diganti dengan kantong kain yang dapat digunakan berkali-kali sehingga limbah plastikpun terkurangi, dan mencegah pencemaran lingkungan

\section{DAFTAR RUJUKAN}

Hadiyati, Ernani. (2011). Kreatifitas dan Inovasi Berpengaruh TerhadapKewirausahaan Usaha Kecil. Jurnal Manajemen dan Kewirausahaan. Vol. 13 No. 1. Universitas Gajayana Malang.

Hamdan. (2018). Industri 4.0 Pengaruh Revolusi Industri Pada Kewirausahaan Demi Kemandirian Ekonomi. Jurnal Nusamba. Vol. 3 No. 2 Universitas Serang Raya.

Hendratni, Thahya Whisnu dan Ermalina. (2013). Womenpreneur

Peranan dan Kendalanya dalam Kegiatan Dunia Usaha. Jurnal Liquitidy. Vol. 2 No. 2. Universitas Pancasila.

Indrayati,Ariyani. (2010). Peranan Wanita Dalam Pemberdayaan Ekonomi Lokal (Studi Kasus Tentang Pola Ruang Belanja Wanita di Daerah Pinggiran Kota Semarang). Jurnal Geografi. Vol. 7. No. 2. Fakultas Ilmu Sosial. Universitas Negeri Semarang.

Ismail, Oki Achmad. 20017. Promosi Kampanye Diet Kantong Plastik Oleh Greeneration Indonesia, Jurnal Ilmu Politik dan Komunikasi, Vol 7 No 1, Universitas Komputer Indonesia.

Julita. (2001). Menuju Kepuasan Pelanggan Melalui Penciptaan Kualitas Pelayanan. Jurnal Ilmiah "Manejemen dan Bisnis. Vol. 1 No. 1. Program Studi Manejemen. Fakultas Ekonomi. Universitas Muhammadiyah Sumatra Utara.

Mardatillah, Annisa. (2012). Peranan Wanita dalam Pengembangan Usaha Kecil Rumah Tangga untuk Meningkatkan Pendapatan Keluarga. Vol. 5 No. 2. JIS. UIR. 
Munfaqiroh, Siti. (2016). Faktor yang Mempengaruhi Wirausaha Wanita Miskin untuk Mencapai Keberhasilan Usaha. Jurnal JIBEKA. Vol. 10 No. 1. STIE Malang.

Musanto, Trisno. (2004)S. Faktor-Faktor Kepuasan Pelanggan dan Loyalitas Pelanggan: Studi Kasus pada CV.Sarana Media Advertising Surabaya. Jurnal Menejemen \& Kewirausabaan. Vol 6 No. 2. Jurusan Ekonomi Manejemen. Universitas Katolik Widya Mandala Surabaya.

Nasution, Reni Silvia. (2015). Berbagai cara penanggulangan Limbah Plastik, journal of Islamic Science and Technology, Vol 1 No 1, UIN Ar-Raniry.

Nurseto, Tejo. (2004). Strategi Menumbuhkan Wirausaha Kecil Menengah yang Tangguh. Jurnal Ekonomi dan Pendidikan. Vol. 1 No. 1. Universitas Negeri Yogyakarta.

Pramiati Purwaningrum. (2016). Upaya Mengurangi Timbulnya Sampah Plastik di Lingkungan. JTL. Vol. 8 No. 2. Jurusan Teknik Lingkungan. Universitas Trisakti.

Santoso, Imam. (2014). Masalah Dan Tantangan Pengembangan Kewirausahaan Pada Kalangan Mahasiswa di Indonesia. Jurnal Inovasi dan Kewirausahaan. Vol. 3 No. 1. Universitas Jendral Soedirman.

Saputri, Rizki Kusumadewi \& Fathul Himam. (2015). Mindset Wanita Pengusaha Sukses, Jurnal Psikologi, Vol 42 No 2, Universitas Gadjah Mada.

Sofia, Irma Paramita. (2015). Konstruksi Model Kewirausahaan Sosial (Social Entrepreneurship) sebagai gagasan Inovasi Sosial Bagi Pembangunan Perekonomian, Jurnal Universitas Pembangunan, Vol 2 No 2, Universitas Pembangunan Jaya.

Sukirman. (2017). Jiwa Kewirausahaan dan Nilai Kewirausahaan Meningkatkan Kemandirian Usaha Melalui Perilaku Kewirausahaan. Jurnal Ekonomi dan Bisnis. Vol. 20 No. 1. Fakultas Ekonomi. Universitas Muria Kudus.

Wanda. (2019). Upaya Menanggulangi Limbah Sampah Plastik dari Belanda.JOM FISIP. Vol. 6 No. 1. Jurusan Ilmu Hubungan Internasional. Universitas Riau.

Wijoyo, Andria. (2014). Pengaruh Variable Marketing Mix terhadap Customer Loyalty Honda Ramayana Basuki Rachmad dengan Customer Satisfaction sebagai Variable Intervening. Jurnal 
Fika Ifazati dan Mita Nur Safitri

Menejemen Pemasaran Petra. Vol. 2 No. 1. Program Menejemen Pemasaran. Universitas Kristen Petra. 